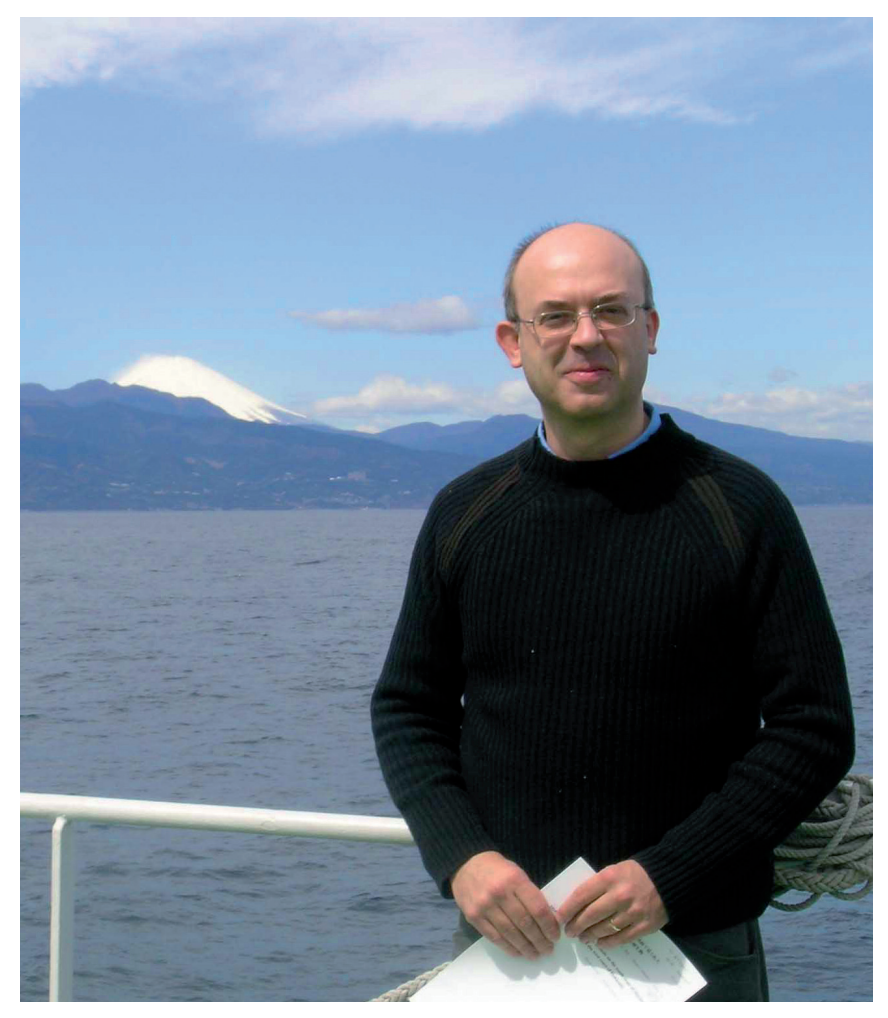

\title{
Francesc Pagès (1962-2007)
}

Nuestro compañero y amigo Francesc Pagès nos dejó para siempre el pasado sábado 5 de mayo 2007. $\mathrm{Su}$ muerte nos ha sorprendido a todos. Francesc estaba en la plenitud de su carrera científica con la vitalidad y entusiasmo que le caracterizaba. Sucedió justo al volver de Plymouth, ciudad en la que estaba organizando el workshop de la Hyrozoan Society. La pasión por este grupo de organismos, los hidrozoos, fue el motivo por el que nos conocimos. Aún recuerdo el primer día que vino al Departamento de Ecología de la Universidad de Barcelona cuando aún cursaba el penúltimo año de carrera hace 25 años. En ese momento yo estaba centrado en mi Tesis Doctoral y me sorprendió que una persona tan joven tuviera tan claro su interés profesional. Nuestra amistad comenzó de forma inmediata y tuve la inmensa suerte de contar con su ayuda en esta fase importante de nuestro trabajo. Otra gran sorpresa fue su incipiente pero ya importante conocimiento sobre la biología del grupo. A partir de entonces ya no dejamos nunca de colaborar.
Empezó una larga aventura profesional y de amistad que podría llenar cientos de páginas de una historia. A lo largo de este corto pero intenso camino Francesc fue desarrollando una impresionante actividad profesional hasta llegar a ser uno de los especialistas más reconocidos de su campo, la biología del zooplancton gelatinoso, a nivel internacional. Entregado por completo a su familia y a su trabajo viajó por todos los océanos de este Planeta, desde el Mediterráneo, su punto de referencia, al océano Atlántico sur donde desarrolló su trabajo de Tesis Doctoral, al océano Antártico en su etapa postdoctoral y a los océanos Pacífico e Índico donde se sumergió en sus profundidades a bordo de submarinos. Donde iba hacía amigos y era un excelente embajador de nuestro Instituto, de su País y de su cultura. Vivía como nadie la pasión por el mar y muy especialmente por los organismos que lo habitan. Amable y afectuoso con sus amigos derrochaba siempre simpatía y generosidad. Su capacidad de asimilar información y de generar conocimiento me 
sorprendió siempre hasta el punto que ha sido uno de mis maestros en los últimos años. Nos ha dejado un científico joven, incansable trabajador y honesto. Una persona cariñosa y amable. Mucho más que un amigo que nunca podré olvidar. Ha dejado un profundo hueco en nuestras vidas que nadie podrá llenar. Permitidme que acabe estas palabras con una frase en la lengua con la que nos comunicábamos y

Our colleague and friend Francesc Pagès passed away on 5 May 2007 on his return from Plymouth, where he was organising the Workshop of the Hydrozoan Society. Francesc was at the height of his scientific career and displayed his usual vitality and enthusiasm, and his death therefore came as a shock to all of us.

Our passion for hydrozoans was the reason for our first meeting. I still remember the day, 25 years ago, when he first came to the Ecology Department of the University of Barcelona. He was still in the last year of his degree and I was working on my doctoral thesis. I was surprised that a person of that age should have such a clear professional interest. Our friendship began immediately and I was fortunate enough to receive his help in this important stage of our work. Another great surprise was his incipient but already considerable knowledge of the biology of hydrozoans. From then on we never ceased to collaborate, and it marked the beginning of a professional and personal adventure that could fill hundreds of pages. During his short but intense career Francesc's achievements were impressive, and he gained a world-wide reputation as one of the most highly-recognised specialists in his field, the biology of gelatinous zooplankton. Fully devoted to his family and his work, he sailed over all the oceans of the Earth, from his reference point in the Mediterranean to the South Atlantic oceans where que él tanto amaba: benvolgut Francesc, amic $i$ company, quant et trobarem a faltar. Ara ens queda lluitar per al teu record.

JOSEP-MARIA GILI Institut de Ciències del Mar

he worked on his doctoral thesis, to the Antarctic Ocean at his postdoctoral stage and later to the Pacific and Indian Oceans, whose depths he explored on board submarines. Wherever he went he made friends, and he was an excellent ambassador of our Institute and of his country and culture. His passion for the oceans, and particularly for the organisms that inhabit them, was unparalleled. He was kind and affectionate to his friends and always showed great geniality and generosity. His capacity to assimilate information and to generate knowledge always surprised me, to the extent that in recent years he has been one of my masters. We have lost a young scientist whom I will never forget - a tireless, hard-working and honest colleague and an affectionate and friendly person who was far more than a friend. He has left a deep gap in our lives that no one can fill. Let me finish these lines with a few words in the language, the Catalan, in which we communicated and which he loved so much:

Benvolgut Francesc, amic $i$ company, quant et trobarem a faltar! Ara ens queda lluitar per al teu record.

(Dear Francesc, my friend and companion, how we will miss you! Now we must fight for your memory.)

JOSEP-MARIA GILI Institut de Ciències del Mar 